\title{
Successful Treatment of Non-Hodgkin's Lymphoma in a Patient with Common Variable Immunodeficiency
}

\author{
Taisuke Ohnoshi, Kyoichi Hayashi, Shinnya Tagawa, Seiji Saito, Seiji Matsutomo, \\ Kunihiro KaWASHIMA and Ikuro KIMURA
}

\begin{abstract}
A case of common variable immunodeficiency' (CVID) who developed non-Hodgkin's lymphoma (NHL) of the rectum is reported. A 22-year-old male student in whom CVID was diagnosed at 7 years of age was referred to our department for the treatment of rectal NHL. The patient had stage IE disease confined to the rectum after clinical diagnostic procedures. He was initially treated with radiation therapy alone, but a relapse soon occurred in the paraaortic lymph nodes. He was successfully treated with CHOP-Bleo chemotherapy and supplementation with immunoglobulin preparations. He has since remained free of NHL and infectious complications for over 30 months despite his persistent immunodeficiency.

(Internal Medicine 32: 152-155, 1993)
\end{abstract}

Key words: rectum, radiation therapy, chemotherapy

\section{Introduction}

The association between malignancy and immunodeficiency is well established $(1,2)$. Common variable immunodeficiency (CVID) is characterized by depressed serum immunoglobulin levels, a decreased ability to produce antibodies in response to antigenic challenge and frequent abnormalities of cellular immune functions, and clinically, by sinopulmonary infections and an increased risk of malignancy. To date more than 100 malignant tumors associated with CVID have been reported in Western countries (1-5). Non-Hodgkin's lymphoma (NHL) is the predominant malignancy in CVID patients, accounting for 47 to $64 \%$ of all tumors $(1,3)$. An approximate 5-fold increase in cancer risk, due mainly to a large excess of stomach cancer (47-fold) and NHL (30-fold), was reported by Kinlen et al following a prospective study of cancer in CVID (5). In Japan, however, only a small number of such cases has been recorded to date. Kobayashi et al reported 4 malignant lymphomas among 112 CVID patients (89 children and 23 adults) who were registered between 1975 and 1986 (6). Kano et al listed 5 cases of malignant lymphoma among 89 adults with CVID, collecting the data mainly by inquiries between 1974 and 1982 (7).

We report here an adult CVID patient who developed NHL in the rectum. Initially radiation therapy failed; but he was later successfully treated by CHOP-Bleo chemotherapy without the development of any severe infectious complications.

\section{Case Report}

A 22-year-old male college student was referred to our department for the treatment of NHL originating in the rectum in March 1989. Apart from having common childhood diseases such as measles, mumpus, varicella and rubella, the patient was genarally healthy until the age of 7 years when he was hospitalized for bacterial pneumonia and diagnosed as having CVID. He then remained fairly healthy, despite occasional sinopulmonary infections and/or otitis media, until 22 years of age when he presented with difficulty of defecation and bloody stools in February 1989. His previous infectious episodes had been successfully treated using antibiotics and supplementation with immunoglobulin preparations. His parents and an elder sister had no signs of immunodeficiency.

Proctoscopy performed at the referring hospital had revealed a bulky mass lesion on the left anterolateral wall of the rectum. The tumor was uneven, covered with eroded mucosa, and bled easily. Biopsy specimens showed the histologic feature of diffuse large cell lymphoma (Fig. 1).

From the Second Department of Medicine, Okayama University Medical School, Okayama

Received for publication July 10, 1992; Accepted for publication December 15, 1992

Reprint requests should be addressed to Dr. Taisuke Ohnoshi, the Second Department of Medicine, Okayama University Medical School, 2-5-1, Shikata-cho, Okayama 700, Japan 

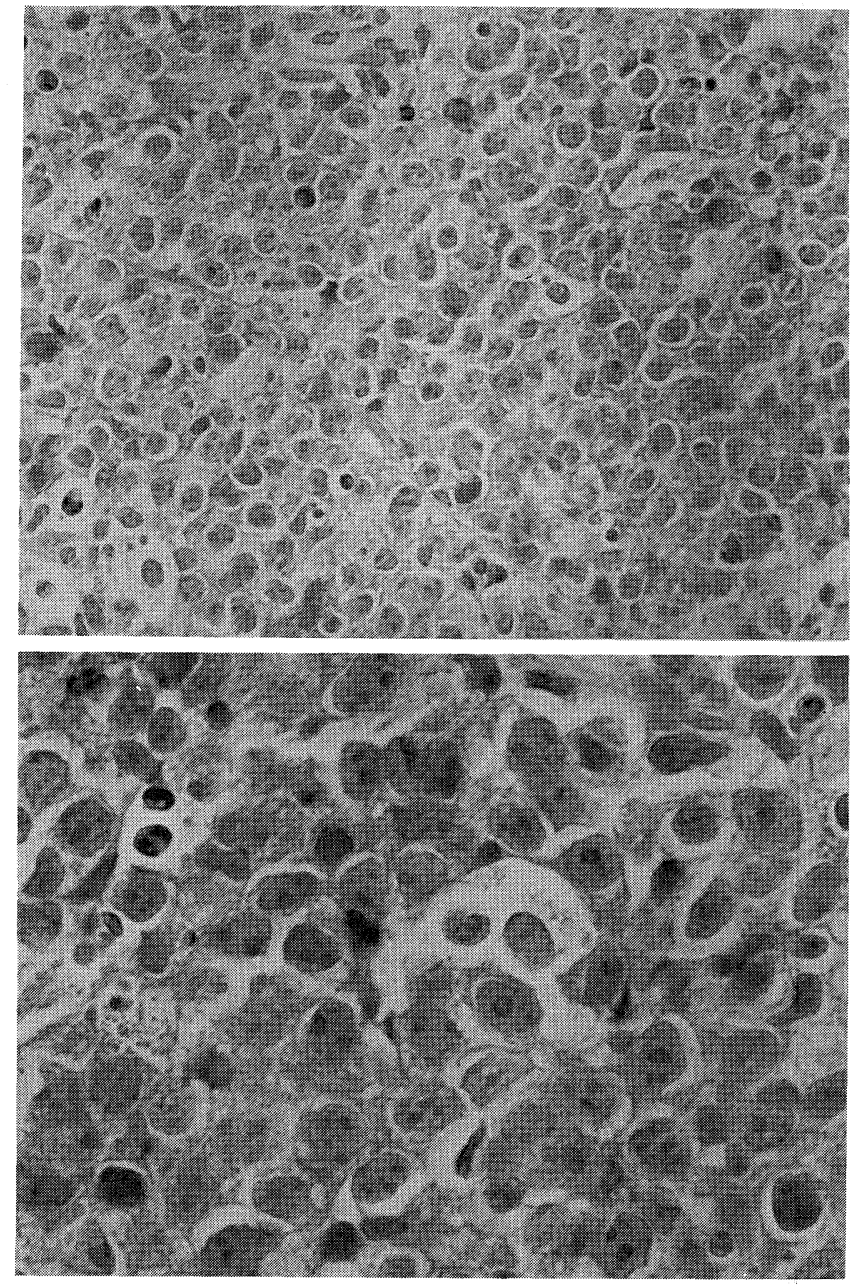

Fig. 1. Histology of the rectal tumor showing diffuse large cell lymphoma (HE stain: upper $\times 200$, lower $\times 400$ ).

He was referred to our department on March 10, 1989. Physical examination on admission showed no abnormalities, except for a bulky rectal mass which was elastic-firm and uneven. The complete blood count revealed mild leukocytosis $(11.800 / \mu \mathrm{l})$, but differential leukocyte count was normal with $31 \%$ lymphocytes. Blood chemistry tests also showed no specific abnormalities. However, the albumin/globulin ratio was abnormally high due to a decreased serum globulin level. Bone marrow aspiration showed normal cytology, except for the total absence of plasma cells. Chromosomal examination of phytohemagglutinin (PHA)-stimulated peripheral lymphocytes showed a normal male karyotype of $46, \mathrm{XY}$. Since the patient refused to undergo tumor biopsy at our department, phenotypic analysis of the tumor could only be done for pan-B antibody staining using paraffin-embedded specimens from the previous hospital. The tumor showed a positive reaction with the antibody, indicating that it probably had a B cell phenotype.
Immunological examination (Table 1) disclosed markedly decreased levels of $\mathrm{IgG}(71.9 \mathrm{mg} / \mathrm{dl}), \operatorname{IgA}$ $(6.9 \mathrm{mg} / \mathrm{dl})$, IgM $(10.2 \mathrm{mg} / \mathrm{dl})$, and $\operatorname{IgE}(0.1 \mathrm{U} / \mathrm{ml})$. Ceruloplasmin and C-reactive protein levels were slightly elevated, but the $\alpha_{1}$-antitrypsin level remained normal. The delayed cutaneous reaction was negative for purified protein derivative and Candida antigen. Epstein-Barr virus antibody was negative for $\mathrm{VCA} \operatorname{IgG}, \operatorname{IgM}$, and IgA and EA-DR IgG, IgA, and EBNA. The blastogenic responses to PHA and concanavalin-A were normal. Flow cytometry of peripheral lymphocytes showed the normal proportion of $\mathrm{T}(79 \%)$ and $\mathrm{B}$ cells $(12 \%)$. T cell subset analysis revealed a decrease of CD4+ cells $(32 \%)$ and an increase of $\mathrm{CD} 8+$ cells $(53 \%)$, resulting in a low $\mathrm{CD} 4+/ \mathrm{CD} 8+$ ratio of 0.6. Natural killer cell activity was diminished when determined as the ratio of Leu7 to Leu11c cells.

Since the patient was diagnosed as having stage IE disease confined to the rectum (Fig. 2) after extensive staging examinations including CT scan and MRI, radiotherapy was started on March 23, 1989. He achieved a complete response after a total of $44 \mathrm{~Gy}$ of irradiation to the pelvic region. He discharged on May 22, 1989, but presented again with left flank pain in late June of the same year. MRI disclosed a relapsing disease, demonstrating bulky paraaortic lymph node enlargement adjacent to the irradiated field (Fig. 3). The patient was subsequently treated with CHOP-Bleo chemotherapy consisting of cyclophosphamide, doxorubicin, vincristine, prednisolone, and bleomycin. In order to prevent infection, he was nursed in a clean environment while receiving chemotherapy and was given intravenous immunoglobulin at a dose of $10 \mathrm{~g}$ immediately after each chemotherapy cycle. He finally achieved a complete response in October 1989 after the 5th cycle of CHOPBleo. He then received four additional cycles of CHOPBleo and was discharged in December 1989. This patient has subsequently been free of NHL and infections for over 30 months despite his persistent immunodeficiency.

\section{Discussion}

In CVID, defects of both $\mathrm{B}$ and $\mathrm{T}$ lymphocytes have been observed at various steps in the maturation of antigen-responding B cells to antibody-secreting plasma cells under the interaction of $\mathrm{T}$ cells and macrophages $(8-13)$. Examinations in the present case revealed a total absence of plasma cells in the bone marrow despite a normal B cell population in the peripheral blood. Moreover, T cell subset analysis of peripheral lymphocytes disclosed a low $\mathrm{CD} 4+/ \mathrm{CD} 8+$ ratio due to an increase of CD8+ cells. Therefore, it seems most likely that the severe hypogammaglobulinemia in this patient was attributable to the failure of $B$ cells to differentiate into Ig-secreting plasma cells under the interaction of activated CD8+ cells $(8-11)$. The reason why patients 


\section{OHNOSHI et al}

Table 1. Laboratory Data of the Patient on Admission

\begin{tabular}{|c|c|c|c|}
\hline Blood chemistry: & & Immunological test: & \\
\hline Total protein & $5.97 \mathrm{~g} / \mathrm{dl}$ & $\mathrm{IgG}$ & $71.9 \mathrm{mg} / \mathrm{dl}$ \\
\hline Albumin & $4.51 \mathrm{~g} / \mathrm{dl}$ & $\operatorname{Ig} A$ & $6.9 \mathrm{mg} / \mathrm{dl}$ \\
\hline $\mathrm{A} / \mathrm{G}$ ratio & 3.09 & $\operatorname{IgM}$ & $10.2 \mathrm{mg} / \mathrm{dl}$ \\
\hline Total bilirubin & $0.36 \mathrm{mg} / \mathrm{dl}$ & $\operatorname{IgE}$ & $0.1 \mathrm{U} / \mathrm{ml}$ \\
\hline GOT & $12 \mathrm{IU} / 1$ & Ceruloplasmin & $34.5 \mathrm{mg} / \mathrm{dl}$ \\
\hline GPT & $10 \mathrm{IU} / 1$ & $\alpha_{1}$-antitrypsin & $309 \mathrm{mg} / \mathrm{dl}$ \\
\hline ALP & $123 \mathrm{IU} / 1$ & CRP & $1.7 \mathrm{mg} / \mathrm{dl}$ \\
\hline LAP & $40 \mathrm{IU} / 1$ & \multicolumn{2}{|l|}{ Subpopulation of lymphocytes: } \\
\hline yGTP & $11 \mathrm{IU} / 1$ & $\mathrm{~T}$ cell & $79 \%$ \\
\hline $\mathrm{CHE}$ & $174 \mathrm{IU} / 1$ & B cell & \multirow[t]{2}{*}{$12 \%$} \\
\hline $\mathrm{LDH}$ & $275 \mathrm{IU} / 1$ & T cell subset: & \\
\hline Creatinine & $0.88 \mathrm{mg} / \mathrm{dl}$ & $\mathrm{CD} 4+$ & $32 \%(43 \pm 8 \%)^{*}$ \\
\hline \multicolumn{2}{|l|}{ Blood cell count: } & $\mathrm{CD} 8+$ & $53 \%(25 \pm 6 \%)^{*}$ \\
\hline $\mathrm{RBC}$ & $5.03 \times 10^{6} / \mu \mathrm{l}$ & $\mathrm{CD} 4+/ \mathrm{CD} 8+$ ratio & 0.6 \\
\hline $\mathrm{Hb}$ & $14.9 \mathrm{~g} / \mathrm{dl}$ & NK activity (Leu7/Leu11c): & decreased \\
\hline Hct & $44.6 \%$ & \multicolumn{2}{|l|}{ Blastogenic response: } \\
\hline WBC & $11.8 \times 10^{3} / \mu \mathrm{l}$ & SI to PHA & 693 \\
\hline \multirow{2}{*}{$\begin{array}{l}\text { Differential } \\
\text { (Lymphocytes }\end{array}$} & normal & SI to CON-A & \multirow{2}{*}{252} \\
\hline & $31 \%)$ & Delayed skin reaction: & \\
\hline $\mathrm{PL}$ & $270 \times 10^{3} / \mu \mathrm{l}$ & PPD & negative \\
\hline \multirow{6}{*}{$\begin{array}{l}\text { Myelogram: } \\
\text { NCC } \\
\text { E/M ratio } \\
\text { Tumor cells } \\
\text { Plasma cells }\end{array}$} & \multirow{6}{*}{$\begin{array}{c}120 \times 10^{3} / \mu \mathrm{l} \\
0.32 \\
\text { negative } \\
\text { absent }\end{array}$} & Candida & negative \\
\hline & & Anti-HTLV-1 Ab & negative \\
\hline & & Anti-EBV Ab: & \\
\hline & & VCA IgG/IgM/IgA & $<\times 10$ \\
\hline & & EA-DR $\operatorname{IgG} / \operatorname{Ig} A$ & $<\times 10$ \\
\hline & & EBNA & $<\times 10$ \\
\hline
\end{tabular}

( )*: Normal value

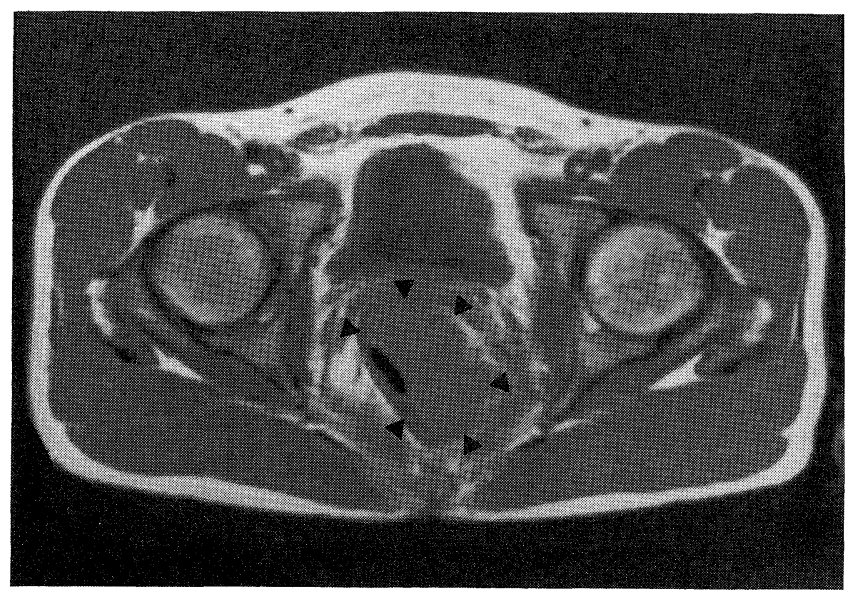

Fig. 2. Coronal MRI of the pelvis at presentation showing a bulky mass lesion arising on the left anterolateral wall of the rectum. The extent of the tumor is indicated by black triangles.

with CVID have a predisposition to develop NHL is still obscure. A number of hypotheses have been proposed, including the absence of immune surveillance (14), continuous exposure to environmental antigens (2), intrinsic chromosomal susceptibility to certain mutagens (15), and uncontrolled B cell proliferation due to im- paired $\mathrm{T}$ cell regulation (16).

Although the details of the pathogenesis of NHL in CVID are unclear, it is evident that NHL shows an increased incidence in CVID patients $(1-5)$. It is usually a $\mathrm{B}$ cell lymphoma that is extranodal in location and predominantly arises in middle age $(2,4)$, although cases of suppressor $\mathrm{T}$ cell (10) or helper $\mathrm{T}$ cell (17) lymphoma have been reported. However, there are few reports on the outcome of treatment of NHL in adult CVID. To our knowledge, only Cunningham-Rundles et al reported on the outcome of 10 patients (one child and 9 adults) undergoing surgery or chemotherapy (4). Six of their 8 patients receiving chemotherapy died of NHL, while the two patients who underwent surgery for early-stage extranodal lymphoma remain alive at 3 and 8 years, respectively. NHL arising in Japanese adults with CVID has only rarely been reported. Although Kano et al listed 5 patients with malignant lymphoma, they did not provide clinical details on the individual patients (7). Accordingly, the present case seemed to be worth reporting this 22-year-old man with CVID who developed diffuse large cell lymphoma, probably of B cell origin. Radiation therapy was a failure but he was successfully treated with CHOP-Bleo regimen (18), which is regarded as a standard therapy for elderly or immunocompromised patients. The patient has been 


\section{NHL in Common Variable Immunodeficiency}

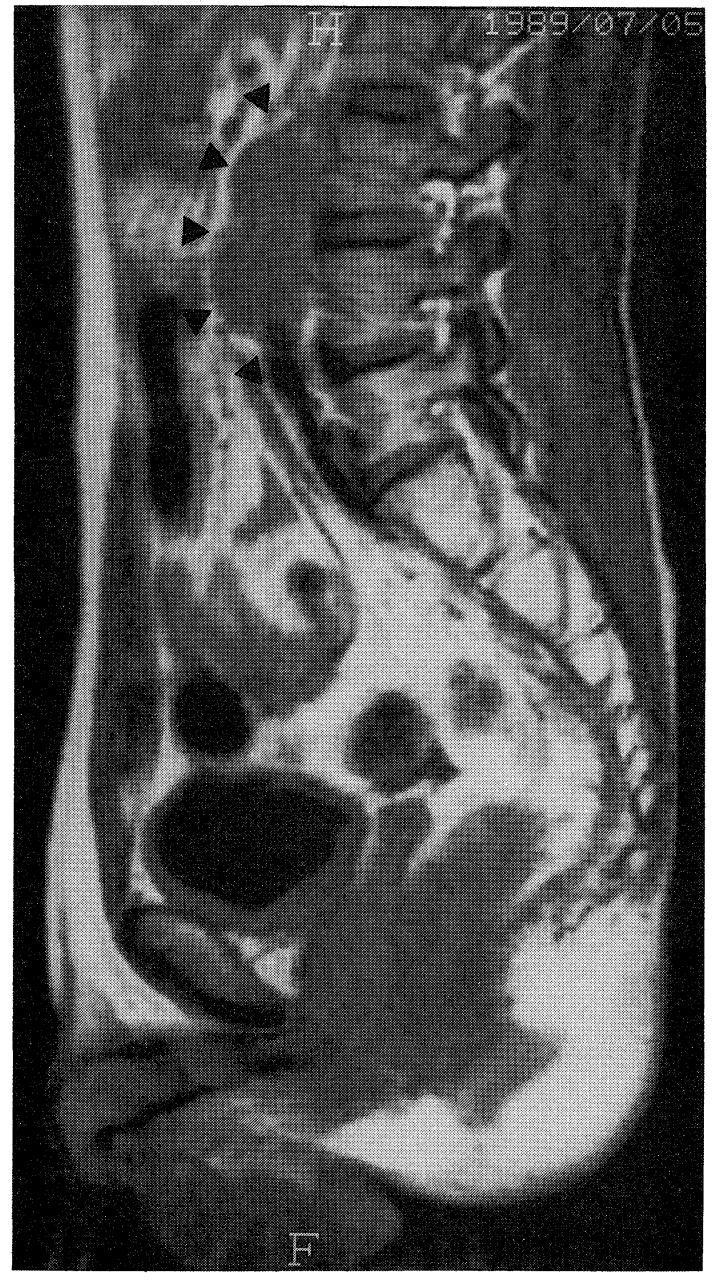

Fig. 3. Sagittal MRI of the abdomen and pelvis at the second admission showing lymphoma in the paraaortic nodes. The extent of the tumor is indicated by black triangles.

well for over 30 months after the completion of chemotherapy, being free not only of NHL but also of severe infection. He might have been cured of NHL, since the majority of relapses in patients with same histology are reported to occur within 2 years after the completion of therapy (19). However, careful follow-up will be necessary, because he is still predisposed to de novo lymphoma as well as to other common malignancies such as stomach cancer $(5-7)$.

\section{References}

1) Filipovich $\mathrm{AH}$, Heinitz KJ, Robinson LL, Frizzera G. The
Immunodeficiency Cancer Registry. A research resource. Am J Pediatr Hematol Oncol 9: 183, 1987.

2) Filipovich AH, Zelbe D, Spector BD, Kersey JH. Lymphomas in persons with naturally occurring immunodeficiency disorders. in: Pathogenesis of Leukemias and Lymphomas: Environmental Influences, Magrath IT, O'Coner GT, Ramot B, Eds. Raven Press, New York, 1984, p. 225.

3) Cunningham-Rundles C, Siegal F, Cunningham-Rundles S, Lieberman P. Incidence of cancer in 98 patients with common varied immunodeficiency. J Clin Immunol 7: 294, 1987.

4) Cunningham-Rundles C, Lieberman P, Hellman G, Chaganti RSK. Non-Hodgkin's lymphoma in common variable immunodeficiency. Am J Hematol 37: 69, 1991.

5) Kinlen LJ, Webster ADB, Bird AG, et al. Prospective study of cancer in patients with hypogammaglobulinaemia. Lancet 1: 263, 1985.

6) Kobayashi N, Naito K, Kudo K, Matsui I, Hayakawa H, Yada J. Primary immunodeficiency syndromes and malignant neoplasms. Gan-no-Rinsho 33: 495, 1989 (in Japanese with English abstract).

7) Kano $T$, Shimada $H$, Uchino $H$, et al. Adult cases of common variable immunodeficiency in Japan. Naika-Hokan 31: 217, 1984 (in Japanese with English abstract).

8) Rosen F, Cooper M, Wedgwood R. The primary immunodeficiencies. N Engl J Med 311: 300, 1984.

9) Siegal F, Siegal M, Good R. Role of helper, suppressor, and B-cell defects in the pathogenesis of hypogammaglobulinemias. N Engl J Med 299: 172, 1978.

10) Durham JC, Stephens DS, Rimland D, Nasser VH, Spira TJ. Common variable hypogammaglobulinemia complicated by an unusual T-suppressor/cytotoxic cell lymphoma. Cancer 59: 271, 1987.

11) Waldmann $T$, Broder $S$, Blaese R, Durm M, Blackman $M$, Strober W. Role of suppressor T cells in pathogenesis of common variable hypogammaglobulinemia. Lancet 2: 609, 1974.

12) Reinherz E, Geha R, Whol M, Morimoto C, Rosen F, Schlossman $\mathrm{S}$. Immunodeficiency associated with loss of $\mathrm{T}_{4}$ inducer cell function. N Engl J Med 304: 811, 1981.

13) Eibl M, Manhalter $J$, Zlabinger $G$, et al. Defective macrophage function in a patient with common variable immunodeficiency. N Engl J Med 307: 803, 1982.

14) Stutman O. Immunological surveillance. in: Origin of Human Cancer, Hiatt HH, Watson JD, Winstern JW, Eds. Cold Spring Harbor Laboratories, Cold Spring Harbor, New York, 1977, p. 729.

15) Verechovsky I, Munzarova M, Lokaj J. Increased bleomycininduced chromosome damage in lymphocytes of patients with common variable immunodeficiency indicates an involvement of chromosomal instability in their cancer predisposition. Cancer Immunol Immunother 29: 303, 1989.

16) Kersey JH, Shapiro RS, Filipovich AH. Relationship of immunodeficiency to lymphoid malignancy. Pediatr Infect Dis J 7: 510, 1988.

17) Kim JH, Bedrosian CL, Schlossman DM. Peripheral T-cell lymphoma complicating common variable hypogammaglobulinemia. Am J Med 85: 123, 1988.

18) Lee R, Cabanillas F, Bodey GP, et al. A 10-year update of CHOP-BLEO in the treatment of diffuse large cell lymphoma. J Clin Oncol 4: 1455, 1986.

19) Skarin AT. Diffuse aggressive lymphomas: A curable subset of non-Hodgkin's lymphomas. Semin Oncol 13 (Suppl 5): 10, 1986. 